\title{
MANAGERIAL ASSESSMENT OF THE PROBLEM OF 50+ EMPLOYEES
}

\author{
Janusz Kroik ${ }^{a}$, Adam Świda ${ }^{b}$ \\ Wroclaw University of Technology, \\ Department of Computer Science and Management, Wroclaw, Poland \\ a e-mail: janusz.kroik@pwr.edu.pl \\ be-mail: adam.swida@pwr.edu.pl
}

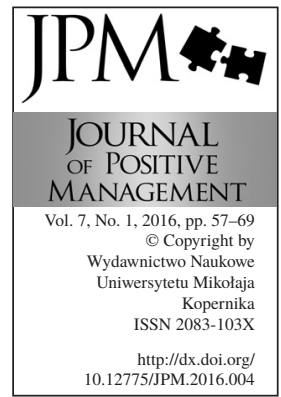

\begin{abstract}
Purpose: Main purpose of the article is to recognize the polish managers attitudes towards a problem of age management and spotting main changes. Some previous scientific research will be the base for the comparison process.
\end{abstract}

Methodology/approach: The importance of the problem of age management in a contemporary enterprise was justified. The basis for the analysis were results of the research conducted among top and middle-level managers. The managers assessed many aspects of this problem. Several of those problems were interpreted in the paper. These were, references to knowledge and views of practices in the scope of development of organizational work potential. A counterpoint for the analyses were results of the national research conducted two years earlier, where the respondents were mainly owners and top managers.

Findings: The empirical results from 2014 year are similar to previous scientific research. It was also confirmed that large enterprises are more involved in the complexity solutions of age management. We can notice positive approach of line managers towards elder workforce.

Implications: In face to old society the problem of employ elder workers will be progressing. Polish organizations should adopt well known standards of age management.

Originality/value of the paper: Empirical researches results have special value for recognizing contemporary and future managerial challenges. Identification these important challenges, could help in formulating firm's personal strategies.

Keywords: age management, discrepancy, labour age structure, employees, discrimination

Paper type: Research paper

\section{Introduction}

The period of prolonging professional activity of employees has been gaining in importance. That's why we need some organizational solutions that ensure benefits both to employers and employees, among others, protecting them against different barriers because of age. Barriers like: relations among cost and efficiency, rising salaries (due to age), less productivity and creativity, risk of absence. Financial 
MANAGERIAL ASSESSMENT OF THE PROBLEM OF 50+

Janusz Kroik

Adam Świda model based on owners welfare versus elder staff introduces many questions and dilemmas. Only wide stakeholders analyse enables identification benefits of elder workers employment (Cichorzewska et al., 2015). The adopted name for these actions is age management (AM). Solving problmes resultet from age management requires suitable preventive measures to be introduced: they will enable promoting and keeping a high level of elderly employees (conventionally marked also with symbol 50+). It has cardinal value at the angle of rising the age of retire. Age management can be considered at three interrelated levels: individual, enterprise, and society (Mendryk, 2013). Each of them involves, however, specific for this level issues. On the corporate level it referring to e.g. productivity, competitiveness, work organization, attitudes towards changes, work environment (Grzesik, 2012). AM should not be regarded as a policy of preferring elderly people: it would be inconsistent with regulations forbidding discrimination (Szukalski, 2008) (including owing to age). On the other hand, the policy of levelling opportunities of people at various age is mentioned (Leśniewska, 2011). Levelling opportunities for elders in organizations needs special strategies and adequate practices. A natural need for analysing the problems of mature employee management [1] is to refer them to various areas of personnel function of an enterprise and even to the personnel strategy seen by specific programs, tools and good practices (Ilmarinen, 2005). Another perspective of AM may be CSR (Corporate Social Responsibility) which contains e.g. approach entitled diversity management, including age diversity management (Wziątek-Staśko, 2012). Age management matches the general formula in business management (Malara, 2014) and even the creation of social innovation supporting business models (Kroik and Malara, 2013). Due to the weight of AM issues, for years various research initiatives in Europe and Poland have emerged, aiming at: examining the situation, developing practical standards, preparing model approaches and measuring commitment of enterprises, obtaining opinions of decision-makers and managers, etc. This paper analyses one of those initiatives, focusing on the search for any possible changes in the approach towards AM. Main aim of the paper is identification the changes in comparison to previous complex research of age management at Poland. Analysed areas referring to four issues: 1. Mangers consciousness about problem of elder workers. 2. Existing solutions and practices of AM. 3. Type of approach: system versus fragmentary. 4. Influence of organization capacity on AM.

\section{Background and research premises}

Premises to conduct research in the area of AM are diverse. Closer research results is included for instance in the paper by Kołodziejczyk-Olczak (KołodziejczykOlczak, 2014). An important and frequent reason for research is a presumption of the significant impact of the climate of age discrimination on efficiency and effectiveness of an organization and the manner of perceiving importance of 
this climate by the management staff. Another research trend is an analysis of solutions applied in practice. These cases, termed as good practices, are intended to combat age barriers, promote age diversity, release potential of the work environment as a whole, maintain preventive character of actions including age context (Kwiatkiewicz, 2010).

There are also researches among concerned workers. Especially a group of employees in mature age, was also subject to research. This group perceives these issues in its own sensitive manner, not only with respect to the context of work organization (ergonomics), but also, in more detail, with respect to needs, hazards, stereotypes, (Wiśniewski and Dolny, 2009),(Hildt-Ciupińska and Bugajska, 2013). Other detailed research by using technique of FGI (Focus Group Interviev) among selected managers groups, were also taken (Moczydłowska, 2014).

The period 2010-2012 in Poland was particularly intensive in terms of research in relation to the period 2003 (first research projects) - 2009 (KołodziejczykOlczak, 2014). Despite these initiatives, the condition of practice in Polish enterprises was considered low, which is proven by the result of comparison to other countries in Europe - leaders in this respect. It is contained in Table 1. The article is positioned in methodical, analytical and improvement stream (Lisiński, 2016).

Table 1.

Disproportions in the approach to age management

in Poland in

comparison with countries-commitment leaders (scale:

1-very seldom, 5-very often)

\begin{tabular}{lcccccc}
\hline Countries & $\begin{array}{c}\text { Length of use } \\
\text { of solutions } \\
\text { with AM }\end{array}$ & $\begin{array}{c}\text { Commonness } \\
\text { and enrooting } \\
\text { of AM in prac- } \\
\text { tice of various } \\
\text { organizations }\end{array}$ & $\begin{array}{c}\text { Interference } \\
\text { of the public } \\
\text { sector in } \\
\text { initiating AM } \\
\text { ideas }\end{array}$ & $\begin{array}{c}\text { Social part- } \\
\text { nership with } \\
\text { other organi- } \\
\text { zations in AM } \\
\text { problem }\end{array}$ & $\begin{array}{c}\text { Range of } \\
\text { respective } \\
\text { instruments in } \\
\text { AM }\end{array}$ & $\begin{array}{c}\text { Priority in } \\
\text { the approach } \\
\text { to the idea } \\
\text { of whole life } \\
\text { learning as } \\
\text { a paradigm } \\
\text { for AM }\end{array}$ \\
\hline $\begin{array}{l}\text { Scandinavian } \\
\text { countries }\end{array}$ & 5 & 5 & 5 & 4 & 4 & 4 \\
\hline Poland & 2 & 1 & 1 & 1 & 1 & 1 \\
\hline
\end{tabular}

The essential of the work is analyse and findings from comparisons of the two empirical results. The time gap among the research is two years. A base of the scientific findings are results of questionnaire research taken in 2014 year by Workers of Department of Management Infrastructure (Faculty of Computer Science and Management - Wroclaw University of Science and Technology). A base for process of comparison were previous (2012 year) research results.

The premise for the analysis of the selected here research initiative from 2014 results from a conviction that after two years from the period of particularly intensive works, in the form of research projects, training projects, papers, as well as after the solidification of knowledge about age management, the situation

Source:

Results from selected countries presented in: (KołodziejczykOlczak, 2014). 
MANAGERIAL ASSESSMENT OF THE PROBLEM OF 50+

Janusz Kroik

Adam Świda

Table 2.

Age structure of operations managers

Source:

Prepared by the author on the basis of: (Lorenc, 2014) and (KołodziejczykOlczak, 2014).

60 in Polish enterprises will change with regard to the conclusion (in a sense it is reflected in Table 1), i.e. small, residual commitment of enterprises in all issues of AM. These conclusions come from research on a large sample of enterprises, which enables treating it as a significant point of view. The source of opinion on the condition and perception of the problem of AM in the selected initiative were not owners /members of boards of directors but managerial personnel of the operating level (lower and middle level). The first group (owners and top management) were well oriented in AM problems. That's why, the knowledge about AM attitudes among line managers were important. Results of the estimation were a base for comparison AM research (point 3.2).

In practice, this personnel may affect fragments of solutions for $50+$ employees, and in a longer period, a broader consideration of employee age. The analysed initiative was conducted before publishing the monograph (Kołodziejczyk-Olczak, 2014) with the results of a complex research of Polish enterprises (quantitative CATI research of employers) conducted in the period March-May 2012. The research was conducted under the project Equalization of opportunities on the labour market for 50+ people [2]. The emergence of such a complex paper (probably the widest research in Poland) gave a premise to compare, as mentioned, the received results of the selected initiative to this diagnosis (the national research).

\section{Analyse and comparison a selected research results}

\subsection{Characterise of respondents and their organisations}

The initiative research was executed in April 2014 on a sample of 100 people holding the assumed managerial positions in different enterprises with the use of a survey questionnaire. This sample was selected in terms of amounts and according to the principle of invitations sent to respondents electronically according to two agreed criteria, i.e. their position and sex. There was also the possibility of agreeing on doubts by email and phone. The sample covered finally 100 people, including 50 women and 50 men, operations managers (low or middle level) from different enterprises, characterized by the age structure indicated in Table 2 [3].

\begin{tabular}{ccc}
\hline Age of the respondents & Number of people & \% \\
\hline Below 25 & 0 & 0 \\
\hline Range 25-34 & 25 & 25 \\
\hline Range 35-44 & 50 & 50 \\
\hline Range 45-54 & 16 & 16 \\
\hline Range 55-64 & 9 & 9 \\
\hline
\end{tabular}


The respondents' age was quite diverse, which suggests that enterprises have a flexible approach with regard to keeping managerial staff. The respondents represented different enterprises in terms of the number of employees. It is presented in Table 3. At the end of the table there is a column with adequate structure that was obtained in the national research, separating in it shares for the research sample total (1011 organisations) and narrowed to the non-public sector (593 organisations). Searching a result from Table 1 we can see that shares for 2014 year results were higher for middle enterprises and lower for microenterprises. The vast majority of the respondents were owners. According to opinion of Kołodziejczyk-Olczak the fact was sourced from image correctness (Kołodziejczyk-Olczak, 2014). The issues of difference will be commented in next points of the paper.

\begin{tabular}{|c|c|c|c|}
\hline $\begin{array}{l}\text { Categories of enterprises by the } \\
\text { number of the employed }\end{array}$ & $\begin{array}{c}\text { Number of } \\
\text { enterprises } \\
\text { in a given } \\
\text { category }\end{array}$ & $\begin{array}{l}\text { Share of a gi- } \\
\text { ven category of } \\
\text { enterprises } \\
(\%)\end{array}$ & $\begin{array}{c}\text { Share of a given } \\
\text { category according to } \\
\text { the national research } \\
\text { (for the total sample } \\
\text { and the group of } \\
\text { non-public sector } \\
(\%: \%)\end{array}$ \\
\hline To 10, microenterprises (MIKP) & 15 & 15 & $27.4: 30.0$ \\
\hline To 50, small enterprises (MAP) & 30 & 30 & $28.1: 29.2$ \\
\hline To 250, average enterprises, (SP) & 36 & 36 & $24.7: 24.6$ \\
\hline Above 250 , large enterprises (DP) & 19 & 19 & $19.8: 16.2$ \\
\hline
\end{tabular}

All medium and large enterprises from which the operations managers come were employing a group of 50+ personnel, and small enterprises were employing them in the vast majority. 10 enterprises were not employing 50+ employees. In the national research, the limit from which a group of employees was considered as mature was $45+$. It is a lowest age limit related to workers age in classifications and scientific researches (Wiśniewski and Dolny, 2009; Leśniewska, 2010). The percentage of enterprises without this group was nevertheless large and accounted for approx. 30\% of 928 entities (Kołodziejczyk-Olczak, 2014). Therefore, the respondents of the analysed initiative were representing enterprises that formally (due to lower age limit and higher share of organisations which don't employ elderly people) approve elderly employees to a greater extent. Distribution of the number of 50+ employees, with breakdown by sizes of enterprises, is included in Table 4.

National research set apart two group of organisations. Traditional with higher share of employee $45+$ and knowledge based organisations with lower share of employee $45+$.
MANAGERIAL ASSESSMENT OF THE PROBLEM OF 50+

Janusz Kroik Adam Świda

Table 3.

Number of enterprises (by the level of employment) from which managers of the operating level came

Source:

Prepared by the author on the basis of: (Lorenc, 2014) and (Kołodziejczyk-

Olczak, 2014). 
MANAGERIAL ASSESSMENT OF THE PROBLEM OF 50+

Janusz Kroik

Adam Świda

Table 4.

Characteristics of share of 50+ employees with breakdown of enterprises by size of employment

Source: (Lorenc, 2014).
Scopes of levels of hiring

50+ employees. Number

of entities in a given range and their share in the range $(\%)$

\begin{tabular}{lccccc}
\hline 1 to 5 & $8(32)$ & $12(48)$ & $4(16)$ & $1(4)$ & $25(100)$ \\
\hline 6 to 15 & $1(4.17)$ & $13(54.17)$ & $9(37.50)$ & $1(4.17)$ & $24(100)$ \\
\hline 16 to 30 & $0(0.00)$ & $0(0.00)$ & $14(87.50)$ & $2(12.50)$ & $16(100)$ \\
\hline Above 30 & $0(0.00)$ & $1(4.00)$ & $9(36.00)$ & $15(60.00)$ & $25(100)$ \\
\hline They do not work 50+ & $6(60.00)$ & $4(40.00)$ & $0(0.00)$ & $0(0.00)$ & $10(100)$ \\
\hline TOTAL enterprises & 15 & 30 & 36 & 19 & 100 \\
\hline
\end{tabular}

\subsection{Consciousness and knowledge of the AM among managers}

Knowledge of the age management at economy and organisations is a peculiar base for shaping awareness of managerial staff and affects undertaken actions, as it has been mentioned before. Sources of information, in research at 2012 year, were firms owners and top management. Results of the research suggest their knowledge about AM. That's why there was a necessity to confirm similar knowledge among line managers (research 2014 year). The similar level of knowledge could support future AM activities (Litwiński and Sztandarska, 2010). In the analysed research initiative, it was conducted at three corners.

First corner is a self-assessment of the level of this knowledge, through the selection of one of five options characterizing this level. It was stated that higher self-assessment enables preparation a more responsible attitudes towards AM in economy and organizations. The data were included in the table below. Findings from Table 5 show certain knowledge of the AM among managers.

Second corner focused on assessment the relations among enterprise competitiveness and age various policy (similar to AM). For example employment of 50+ is treated as an important organizational resource of human capital (Walczak, 2011). It was underlined the validity of age variety at organizational knowledge management (Zając, 2015).

Table 6 presents results of the assessment of premises of business competitiveness under age diversity of employees, one of important contexts in this type of research. 


\begin{tabular}{lcc}
\hline Level and type of available knowledge & $\begin{array}{c}\text { Number of } \\
\text { opinions about the } \\
\text { level of knowledge }\end{array}$ & Share (\%) \\
\hline $\begin{array}{l}\text { High enabling implementation of AM principles in } \\
\text { practice }\end{array}$ & 1 & 1 \\
\hline $\begin{array}{l}\text { General knowledge, additional supplement would } \\
\text { enable implementation of AM principles }\end{array}$ & 29 & 29 \\
\hline $\begin{array}{l}\text { Established but intuitive view on the issues } \\
\text { No knowledge, though it is defined as substantive } \\
\text { message }\end{array}$ & 38 & 24 \\
\hline \begin{tabular}{l} 
I do not know the problem \\
\hline
\end{tabular}
\end{tabular}

MANAGERIAL ASSESSMENT OF THE PROBLEM OF 50+

Janusz Kroik Adam Świda

\begin{tabular}{lccc}
\hline $\begin{array}{l}\text { Does big age diversity in hiring employees con- } \\
\text { tribute to growth in business competitiveness? }\end{array}$ & Woman & Man & Total \\
\hline I definitely agree & 11 & 8 & 19 \\
\hline I rather agree & 26 & 23 & 49 \\
\hline I rather disagree & 10 & 9 & 19 \\
\hline I definitely disagree & 4 & 9 & 13 \\
\hline
\end{tabular}

Table 5.

Self-assessment of knowledge about AM by managers

Source: (Lorenc, 2014).

Table 6. Views of managers on the impact of age diversity of employees on business competitiveness

Source: (Lorenc, 2014).

Women attained greater importance to age diversity on business competitiveness, which may be reflected in the results in detailed contexts of age management. Competitiveness may be supported by proper AM strategy. That strategy is created by managers consciousness, personal strategy and good practices (Cichorzewska et al., 2015).

Third corner relates to market premises. Managers assessed also several general aspects influencing possible practice towards 50+ employees. Two of them are presented in Tables 7 and 8 . The issue is the weight of the management problem and the phenomenon of discrimination of elderly people on the labour market.

More than a half of managers concluded that AM is important regardless of economic conditions. Some of them took a neutral stance i.e. treating it as a standard personnel problem. Research results show that vast majority of managers accept implementing AM standards at enterprise. 
Table 7. Weight of management problem for contemporary enterprises arising from the issue of approach to 50+ employees

Source:

(Lorenc, 2014).

Table 8.

Views of managers on the phenomenon of discrimination of $50+$ people on the labour market

Source:

(Lorenc, 2014).

\section{Type of perception of the meaning of 50+ employees}

Number of

$\%$

It is an important management problem regardless of situation on the labour market and condition of the economy

It is an important problem with market pressure and adequate economic situation

It is an important problem in the event of favourable regulations giving additional, measurable benefits to employers

$53 \quad 53$

53

The issue should be treated as a standard personnel problem

There are no premises to treat the issue as an important
11

11

16

18

$18 \quad 18$

2

In the national research employers created a kind of tactics of image correctness. On the one hand, the recorded major percentage of indications as to the use of various AM tools was not consistent with the statement that for almost all employers (95\%) age is not important and what counts are work results (Kołodziejczyk-Olczak, 2014).

The perception of the problem for 50+ people from the perspective of labour market and its characteristics (business environment) related, among others, to the phenomenon of discrimination. The vast majority of managers agreed with its existence (Table 8).

The fact that the phenomenon of discrimination is noticed by almost $90 \%$ people confirms that it requires determination in dealing with many barriers comprising this assessment.

\begin{tabular}{llccccc}
\hline $\begin{array}{l}\text { Number of 50+ } \\
\text { employees }\end{array}$ & $\begin{array}{l}\text { Assessment of the } \\
\text { phenomenon of } \\
\text { discrimination }\end{array}$ & $\begin{array}{c}\text { Definitely } \\
\text { YES }\end{array}$ & $\begin{array}{c}\text { Rather } \\
\text { YES }\end{array}$ & $\begin{array}{c}\text { Definitely } \\
\text { NO }\end{array}$ & $\begin{array}{c}\text { Rather } \\
\text { NO }\end{array}$ & TOTAL \\
\hline 1 to 5 & 10 & 13 & 0 & 2 & 25 \\
\hline 6 to 15 & 11 & 11 & 1 & 1 & 24 \\
\hline 16 to 30 & 8 & 6 & 0 & 2 & 16 \\
\hline Above 30 & 5 & 15 & 2 & 3 & 25 \\
\hline They do not work +50 & 4 & 5 & 0 & 1 & 10 \\
\hline TOTAL enterprises & 38 & 50 & 3 & 9 & 100 \\
\hline
\end{tabular}


Summarising - line managers have positive attitudes towards employment of elderly workers. It is similar to results from 2012 research. It was stated that a basic criteria for employment is labour efficiency.

\subsection{Solutions and practices in the scope of development elder employees}

The analysis of 14 Polish authors indicating sources of activities for AM (Kołodziejczyk-Olczak, 2014) made it possible, in simplification, to select 9 areas of the personnel function for the proactive approach. Two of the areas are in almost each proposal (13 authors). They were: development of labour capacity (as a base for comparisons) and configuring a labour. Other were recorded only once: e.g. periodic appraisal of employees. It should be emphasized that only few authors emphasize the personnel policy and strategy as a source of AM practices. The newest articles stright join the AM with personal strategy (Grzesik, 2012), (Rębiasz, 2015), (Cichorzewska et al., 2015). It results also from the national research where only $10.8 \%$ of employers from the distinguished there, the socalled knowledge-based organizations (kbo) were planning employment including age, much less than the so-called traditional organizations-18.8\% (KołodziejczykOlczak, 2014).

Results of the analysis of the initiative for the area of potential development were focused on the assessment tools (with age limits for their apply. Age restrictions were analysed in the case of planning development-oriented activities (training, courses, complex programs) and forms of involving (using) $50+$ employees in development processes. Total lack of age restrictions was indicated in $29 \%$ of the surveyed enterprises. Only $31 \%$ declared the impact of age (to a different extent) in decisions on training, and other statements indicated employee needs 9\% and combining employee and employer's needs: $31 \%$. In 28 cases the need for using knowledge and skills of 50+ employees in developmentoriented activities was not indicated. The active forms using 50+ employees were definitely dominated by three: on-the-job training: 30 indications, transferring current experience: 28 cases, and mentoring and coaching: 31 cases (Lorenc, 2014). Analysing the national research in this respect, the so-called traditional organizations declared positively: on-the-job training and current experience in $51.9 \%$, and in knowledge-based organizations in 38\%. The third tool was assessed at the level of $32.7 \%$ in traditional organizations and $47.7 \%$ in knowledge-based organizations (Kołodziejczyk-Olczak, 2014). The obtained results from 2014 year are thus close to entities with traditional status. It means positive approach for elderly workers at organisations (knowledge-based organisations).

\subsection{Assessment of system approach to AM}

The aspect of system character of the approach to shaping developmentoriented solutions may be identified with the assessment of complexity versus
MANAGERIAL ASSESSMENT OF THE PROBLEM OF 50+

Janusz Kroik Adam Świda 
Table 9.

Thae managers' assessment of activities of enterprises in terms of system character in the field of shaping motivation of 50+ employees, by way of development potential, promotions

Source:

(Lorenc, 2014). fragmentation of the used solutions. In research conclusions for enterprises operating in Poland (to 2012) the existence of age management systems was not indicated. Indirect dimension that state are synthetic indicators for measuring proactive approach to AM. In the analyzed initiative this problem was considered with regard to type of approach to the development, promotion and motivation of $50+$ employees. System approach influences other areas of FM. The results are included in Table 9.

\begin{tabular}{lc}
\hline $\begin{array}{l}\text { Approach to age management in an enterprise in the scope of development, } \\
\text { promotion, motivating }\end{array}$ & $\begin{array}{c}\text { Number of } \\
\text { assessments }\end{array}$ \\
\hline System, operating already for a long time & 13 \\
\hline System, introduced recently & 10 \\
\hline At best fragmentary, previously more complex & 16 \\
\hline No actions in this area & 61 \\
\hline
\end{tabular}

The obtained results may be considered, however, as relatively beneficial in the light of interpretation of findings of the national research. The obtained there synthetic indicator W1 [4], describing the attitude of enterprises to strengthening personal resources, i.e. to developing competences of mature employees (one of 5 age management strategy according to M. Wallin, T. Hussi (Wallin and Hussi, 2011) was, as average for all enterprises, 2.39 (maximum 10 points). It is comparable from 23 indications about system approach from table 9 (but without considering 13 cases with fragmentary approach).

\subsection{Organisation capacity and level of engagement to $A M$}

In comparison the two research of AM, it is worth referring to the key conclusion resulting from the national research, namely that large enterprises (above 250 employed) differ clearly positively (especially towards small organisations) when it comes to proactive age management. Also this issue may be analysed on the basis of the analysed research in the initiative from 2014 year. The cross-section uses in a few situations is the section of achieved performance by enterprises employing a relevant number of 50+ employees (profile given at Table 4). The category in which more than 30 people are employed is, more or less, referred to large companies and medium-sized enterprises from to the upper level of total employment (more than 200 people). The analysis of these cases indicates distinctive assessments for this category of enterprises. Unfortunately, they cannot be referred directly to the context of proactive action of an enterprise for AM. On the other hand, the element concurrent with the 
national findings (for large companies) can be a structure of answers to the key question about the manner of involving in the issues of age management in an enterprise, more precisely their incorporation in the personnel strategy. This is included in Table 10.
MANAGERIAL ASSESSMENT OF THE PROBLEM OF 50+

Janusz Kroik Adam Świda

Does your enterprise take into account the issues of employee age in decisions relating to strategic premises?

\begin{tabular}{lcccccc}
\hline $\begin{array}{l}\text { Size of } \\
\text { enterprise }\end{array}$ & $\begin{array}{c}\text { Yes, it is in- } \\
\text { corporated in } \\
\text { the personnel } \\
\text { strategy }\end{array}$ & $\begin{array}{c}\text { Yes, they are } \\
\text { included in } \\
\text { analyses and } \\
\text { assessments of } \\
\text { consequences }\end{array}$ & $\begin{array}{c}\text { Yes, but it is } \\
\text { a declaration }\end{array}$ & $\begin{array}{c}\text { No, though it } \\
\text { is present in } \\
\text { management } \\
\text { discussions }\end{array}$ & $\begin{array}{c}\text { No, though } \\
\text { they occur in } \\
\text { situational } \\
\text { discussions of } \\
\text { personnel }\end{array}$ & $\begin{array}{c}\text { No, there is } \\
\text { no situation } \\
\text { of raising the } \\
\text { issues of em- } \\
\text { ployee age }\end{array}$ \\
\hline to 10 & 1 & 3 & 4 & 5 & 0 & 2 \\
\hline to 50 & 2 & 5 & 6 & 10 & 4 & 3 \\
\hline to 250 & 1 & 4 & 10 & 11 & 6 & 4 \\
\hline Above 250 & 8 & 1 & 2 & 3 & 1 & 4 \\
\hline
\end{tabular}

This comparison is general and statement on compliance with the findings of national research from 2012 results from the definitely greatest number of large enterprises for companies having a reference of the problem to the personnel strategy (in this category 8 per 12 cases, see tab. 13, first column). A big high number of enterprises in which the problem of mature employee age is raised by the management also attains attention (without the strategic context- 29 cases). The question whether or not this discussion will result in further steps towards approaching linkages with the personnel strategy remains open. Smaller number of cases of references to the strategy for small enterprises in relation to large enterprises (in the national research from 2012 or in the initiative from 2014) are, to a large extent, a consequence of using simplified approach to human resource management (Nogalski et al., 2010).

\section{Conclusions}

The analyses of the initiative from 2014 year presented in the paper referred to the national research indicate a similar assessment of the phenomenon and practices in companies concerning the employment o elderly workers. This conclusion emerges in spite of the fact that 2-4 years elapsed between the studies and that the group of respondents was different, i.e. on the one hand owners and boards of enterprises that care for the image aspect of the run enterprise, while on the other lower and middle-level managerial staff without these inclinations. Additionally, any possible changes could have been determined by the state of
Table 10. Strategic perspective of employee age by operations managers

Source: (Lorenc, 2014). 
MANAGERIAL PROBLEM OF 50+

Janusz Kroik Adam Świda ASSESSMENT OF THE

respondent's knowledge (from 2014 year) being a derivative of many undertaken research initiatives and training initiatives. Some influences sourced from the balanced selection of the sample based on sex. Thus, despite many premises encouraging different expectations (views and practices), such a difference cannot be noted.

A positive phenomenon is fact, that managers (research from 2014 year) spotted system approach in implementing processes. Their share is bigger than shares from previous research (project 2010-2012 years). Other researches (Moczydłowska, 2014) pointed that pressure and consciousness, about necessity of changes at AM area, is rising. Moreover implemented practices of AM confirm benefits for employers and employee 50+. The analysed research initiative took place, as it has been mentioned, in the period before publishing comprehensive national research, therefore caution was exercised when comparing the findings. Mentioned, at the beginning of the paper, possibilities to appear a questions and dilemmas of elderly workers employment may support the wide stakeholder analyse. Idea of AM could be analysed at the paradigm of unique structures of society generations (Lisiński, 2016). The paradigm is also a new source of questions and dilemmas.

\section{References}

Cichorzewska, M., Mazur, B., Niewiadomska, A., Sobolewska-Poniedziałek, E., Zimnoch, E., Ziółkowska, B. (2015), Zarządzanie wiekiem. Aspekt regionalny, instytucjonalny i organizacyjny, Politechnika Lubelska- seria monografie, Lublin.

Grzesik, M. (2012), Motywy wdrażania strategii zarzadzania wiekiem w przedsiębiorstwie, Przedsiębiorstwo we wspótczesnej gospodarce - teoria i praktyka, Politechnika Gdańska, Gdańsk, nr 2.

Hildt-Ciupińska, K., Bugajska, J. (2013), "Evaluation of activities and needs of older workers in the context of maintaining their employment", Medycyna Pracy, Vol. 64 No. 3, pp. 1-2.

Ilmarinen, J. (2005), Towards a Longer Worklife! Ageing and the Quality of Worklife in the Europiean Union, Finninish Institute of Occupational Health, Ministry of Social Affairs and Health, Helsinki.

Kołodziejczyk-Olczak, I. (2013), "Zarządzanie wiekiem w sektorze MSP jako wyzwanie" in: Marjański, A., Sułkowski Ł. (Eds.), Firmy Rodzinne - wyzwania globalne i lokalne, Wydawnictwo Społecznej Akademii Nauk, tom XIV, zeszyt 6, część III, Łódź, pp. 61-72.

Kołodziejczyk-Olczak, I. (2014), Zarzadzanie pracownikami w dojrzałym wieku, wyzwania i problemy, Wydawnictwo Uniwersytet Łódzki, Łódź.

Kroik, J., Malara, Z. (2013), "Innowacje społeczne jako przesłanka modelu biznesowego", Zeszyty Naukowe, Ostrołęckie Towarzystwo Naukowe, No. 27, pp. 354-368.

Kwiatkiewicz, A. (2010), Analiza dobrych praktyk dotyczacych zarządzania wiekiem w polskich przedsiębiorstwach - studium przypadku, PARP, Warszawa. 
Lisiński, M. (2016), "Paradygmaty metodologiczne nauk o zarządzaniu”, Prace Naukowe Uniwersytetu Ekonomicznego we Wrocławiu, (sieci organizacyjne, procesy i projekty w erze paradoksów), nr 421, pp. 374-385.

Litwiński, J., Sztandarska, U. (2010), Wstępne standardy zarzq̨dzania wiekiem w przedsiębiorstwach, PARP, Warszawa.

Lorenc, A. (2014), Zarzqdzanie wiekiem jako element funkcji personalnej, Politechnika Wrocławska, Wrocław.

Malara, Z. (Ed.) (2014), Przyzwoitość w zarzqdzaniu, Wydawnictwo Politechnika Wrocławska, Wrocław.

Mendryk, I., (2013), "Przesłanki wprowadzania polityki zarządzania wiekiem w polskich przedsiębiorstwach”, Zeszyty Naukowe Uniwersytetu Marii Curie-Skłodowskiej, Vol. XLVII (2), Lublin.

Moczydłowska, J. M. (2014), "Mentoring jako narzędzie zarządzania wiekiem" Przedsiębiorczość i Zarządzanie, tom XV, zeszyt 11, część I, pp. 181-193.

Nogalski, B., Wojcik-Karpacz, A., Karpacz, J. (2010), "Identyfikacja form zatrudnienia w małych i średnich przedsiębiorstwach budowlanych w świetle wyników badań empirycznych", in: Matejun, M. (Ed.), Wyzwania i perspektywy zarzadzania matych i średnich przedsiębiorstw, Wydawnictwo CH Beck Warszawa, pp. 137-153.

Rebiasz, M. (2015), "Rola strategii zarządzania wiekiem w przedsiębiorstwie", Studia i Prace Wydziat Nauk Ekonomicznych i Zarzadzania Uniwersytet Szczeciński, Nr 39, t. 3, pp. 155-167.

Szukalski, P. (2008), "Ageizm - dyskryminacja ze względu na wiek”, in: Kowaleski, J., Szukalski, P. (Eds.), Starzenie się ludności Polski-między demografią a gerontologia społeczna, Wydawnictwo Uniwersytetu Lódzkiego, Lódź, pp. 153-184.

Walczak, W. (2011), Zarzq̨dzanie różnorodnościa jako podstawa budowania potencjału kapitału ludzkiego organizacji, SGH, Warszawa, E-mentor, nr 3 (40).

Wallin, M., Hussi, T. (2011), Best practices in Age Managenent- Evaluation of Organisation Cases. Final report, Finnish Work Environment Fund, Helsinki.

Wiśniewski, Z., Dolny, E. (2009), "Charakterystyka projektu badania sondażowego osób starszych", in: Wiśniewski, Z. (Ed.) Zarzadzanie wiekiem w organizacjach wobec starzenia się ludności, TNOIK, Dom Organizatora, Toruń, pp. 65-74.

Wziątek-Staśko, A. (2012), Diversity Management. Narzędzie do skutecznego motywowania pracowników, Difin, Warszawa.

Zając, M. (2014), “Znaczenie różnorodności wiekowej pracowników w kontekście wybranych obszarów zarządzania wiedzą w organizacji”, Zeszyty Naukowe Politechniki Częstochowskiej, Zarządzanie, nr 15, pp. 25-36.
MANAGERIAL ASSESSMENT OF THE PROBLEM OF $50+$

Janusz Kroik Adam Świda 